\title{
Diversity and Coverage of Coral Reefs in the Olele Regional Marine Conservation Area, Gorontalo
}

\author{
Asniati Ningsi, Ida Astuti, dan Ramdan Monoarfa
}

\begin{abstract}
Olele Marine Park is one of the Regional Marine Conservation Areas (KKLD) which is designated as a conservation area based on the Decree of the Regent of Bone Bolango No. 165 of 2006. As one of the Marine Parks, the Olele KKLD provides a coral reef ecosystem which is an important asset in attracting local and foreign tourists to visit. Seeing tourism activities in the area referred to by monitoring and observing the condition of coral reefs is a big concern to do for the sake of ecosystem sustainability in the future. This study aims to study the extent and extent of coral cover in the Olele Regional Marine Protected Area. This research was conducted in April to May 2019 in Olele Village. The study used the LIT method at three stations at depths of 2 and 4 meters. The results showed station $I$ depth 2 and $4 \mathrm{~m}$ wide coral cover $12.8 \%$ and $22.9 \%$ classified as bad, station II coral cover area $24.1 \%$ and $37.5 \%$ classified as poor on the surface of $2 \mathrm{~m}$ and moderate at height $4 \mathrm{~m}$, while at station III the area of coral cover is $86.5 \%$ at a depth of $2 \mathrm{~m}$ and $95.4 \%$ a depth of $4 \mathrm{~m}$ with coral conditions that are still very good. For the index of coral reef diversity in the medium category.
\end{abstract}

Keywords : Cover, Coral reefs, LIT, KKLD, Olele

\section{INTRODUCTION}

Coral reef ecosystems have a good ability to repair damaged parts if the habitat characteristics of various coral reef formations and environmental factors that influence them are well maintained. Lzike other ecosystems, coral reefs do not require direct human intervention or manipulation for their survival (Dahuri, 2003).

One of the Gorontalo areas that have coral reef potential is the Olele marine park conservation area, Bone Bolango Regency, Gorontalo Province. Olele was established by the Bone Bolango government as a Regional Marine Conservation Area (KKLD) since 2006. The coral reef ecosystem in the village of Olele has approximately 16 rock genera and dozens of species, overall the coral genus that dominates the reef distribution, among others Montipora, followed by Acropora, Porites, Fungia, and Pectinta which are spread evenly (DKP Bone Bolango 2006).

Revised Manuscript Received on January 15, 2020.

* Correspondence Author

Asniati Ningsi*, Fisheries and Marine Department, Gorontalo Unversity, Gorontalo, Indonesia. Email: aningsihazis@gmail.com

Ida Astuti, Fisheries and Marine Department, Gorontalo University, Gorontalo, Indonesia. Email: badariadgkanang@gmail.com

Ramdan Monoarfa, Fisheries and Marine Department, Gorontalo University, Gorontalo, Indonesia. Email: ramdanm@gmail.com
The condition of the coral reef ecosystem in the Olele Marine Park Conservation Area is still quite good and varies, especially the types of branched corals, but efforts to monitor and observe the condition of the coral reef must continue to be carried out bearing in mind the marine tourism activities in the Olele Marine Park-Conservation Area are increasingly worried about impact on the condition of coral cover. Seeing tourism activities in the area, efforts to monitor and observe the condition of coral reefs are a big concern to do for the sustainability of the ecosystem in the future. This study aims to determine the diversity and extent of coral cover in the Olele Region Marine Protected Area. This research was conducted from April to May 2019 in Olele Village, Kabila Bone District, Bone Bolango District. The study used the LIT (Line Intercept Transect) method at three stations at depths of 2 and 4 meters. In observing LIT, data recording is in the form of types of coral reefs, percentage of closure based on lifeform.

\section{MATERIALS AND METHODS}

This research was conducted in April-May 2019 in the Olele Marine Park Conservation Area, Gorontalo Province.

\subsection{Tools and Materials}

The tools used during the study were snorkel, underwater camera, roll meter. Refractometer, $\mathrm{pH}$ meter, thermometer, disk secchi and GPS the materials used are coral reefs, coral identification books, and the Coral Finder Toolkit.

\subsection{Sampling Method}

The method used to collect coral reef data is the line intercept transect method. The transect line method is carried out by stretching the transect line in the form of a rolling meter along 10 meters with 6 sampling times at each station that is installed parallel to the coastline with 3 transects at a depth of 2 meters and 3 transects at a depth of 4 meters. In observing line intercept transects, data recording took the form of types of coral reefs, percentage of closure based on lifeform. Measurements by recording the width of each lifeform with accuracy to near centimeters. In this study, one colony is considered one individual. If a colony of the same kind is separated by one or several dead parts, each living part is considered as a separate individual. If two or more colonies grow above the other, then each colony has been counted as a separate colony (English et al, 1997). 


\section{Diversity and Coverage of Coral Reefs in the Olele Regional Marine Conservation Area, Gorontalo}

\subsection{Data analysis}

1. Condition of Coral Cover in the Olele Marine Conservation Area.

The percentage value of coral cover obtained from the measurement of coral lifeforms will be calculated using a formula (Gomez and Yap 1988):

$$
\mathrm{L}=\mathrm{Li} / \mathrm{N} \times 100 \%
$$
L : Percentage of coral cover (\%)
Li: Long lifeform
$\mathrm{N}$ : Transect length

2. Coral Reef Diversity

Species diversity is a community level characteristic based on biological organization and will state the structure of the community. Diversity can be calculated using the Shannon-wiener index (Odum 1993) :

$$
\mathbf{H}^{\prime}=\sum \mathbf{P i} \ln \mathbf{P} \mathbf{i} ;=\mathbf{n i} / \mathbf{N}
$$

$$
\begin{array}{ll}
\mathrm{H} & \text { : Pi index diversity } \\
\mathrm{Pi} & \text { : ni / N (Proportion of k-i Species) } \\
\text { ni } & \text { : Number of individual types } \\
\mathrm{N} & \text { : Total number of individuals }
\end{array}
$$

Information :

$\mathrm{H}^{\prime}<1,0$ : Low diversity and low community conditions

$1,0>\mathrm{H}^{\prime}<3:$ : Medium diversity and moderate community situation $\mathrm{H}^{\prime}>3$

$\mathrm{H}^{\prime}>3$ :High diversity and high community conditions

\section{RESULTS AND DISCUSSION}

\subsection{Condition of Coral Reef Cover in the Olele area Marine Conservation Area}

Based on the results of data analysis, it is known the percentage that of live coral (Lifeform) at Station I, which is near residential areas, is shown in the following tables 1 and 2:

TABLE 1. THE RESULTS OF THE MEASUREMENT OF CORAL COVER STATION I DEPTH OF 2 METERS

\begin{tabular}{|c|c|}
\hline \multicolumn{2}{|c|}{ Station I Depth 2 Meters } \\
\hline Kategory & \% Cover \\
\hline CM & $11.9 \%$ \\
ACD & $0.6 \%$ \\
CMR & $0.3 \%$ \\
\hline Total & $12.8 \%$ \\
\hline
\end{tabular}

Ket: CM (Coral massive), ACD (Acropora digitate) dan CMR (Coral mushroom)

TABLE 2. THE RESULTS OF THE MEASUREMENT OF CORAL COVER STATION I TO A DEPTH OF 4 METERS

\begin{tabular}{|l|l|}
\hline \multicolumn{2}{|c|}{ Station I Depth 4 Meters } \\
\hline Kategory & $\%$ Cover \\
\hline
\end{tabular}
dan CB (Acropora branching) (Coral milepora behaviors that occur include stepping on a coral reef, holding a coral reef and shaking fins. Such contact

coral cover a station I depths 2 and 4 meters are still classified as poor. This is because Station I is close to community settlements and the area is a fishing boat. Coral reefs in the area become a place to tie the anchor of a fishing boat so that it can damage the reef. This is in accordance with the opinion of Sukmara, et al (2002) boat booster or bamboo is a source of threat to coral reefs which then indicate that the coral saplings are broken and died due to being hit by bamboo sticks that are stuck by the fishermen. According to Indarjo, et al, (2004), the potential of coral reef resources in Indonesia is decreasing and threatened to be damaged. The extent of coral cover for Station II is shown in the following table :

Table 3. Measurement Results of Coral Cover II STATION DEPTH OF 2 METERS

\begin{tabular}{|c|c|}
\hline \multicolumn{2}{|c|}{ Station II Depth 2 Meters } \\
\hline Kategory & $\%$ Cover \\
\hline ACE & $13.4 \%$ \\
ACD & $5.1 \%$ \\
CMR & $4.5 \%$ \\
ACB & $1.1 \%$ \\
\hline Total & $24.1 \%$ \\
\hline
\end{tabular}

Ket: ACE (Acropora encrusting), ACD (Acropora digitate), CMR (Coral mushroom),

Table 4. Measurement results of Coral Cover II STATION DEPTH OF 4 METERS

\begin{tabular}{|c|c|}
\hline \multicolumn{2}{|c|}{ Station II Depth 4 Meters } \\
\hline Kategory & $\%$ Cover \\
\hline ACE & $14.4 \%$ \\
ACD & $6.4 \%$ \\
CMR & $4.4 \%$ \\
ACS & $1.1 \%$ \\
ACT & $9.7 \%$ \\
CTU & $0.7 \%$ \\
CME & $0.8 \%$ \\
\hline Total & $37.5 \%$ \\
\hline
\end{tabular}

Ket: ACE (Acropora encrusting), ACD (Acropora digitate), CMR (Coral mushroom), ACS (Acropora submassive), ACT (Acropora tabulate), CTU (Coral tubipora) dan CME

From the measurement of Station II the depth of 2 and 4 meters the percentage of coral cover is in the bad and moderate category. In the area of Station II, many tourists often snorkel so that contact between tourists and coral reefs often occurs, both intentionally and unintentionally. Contact

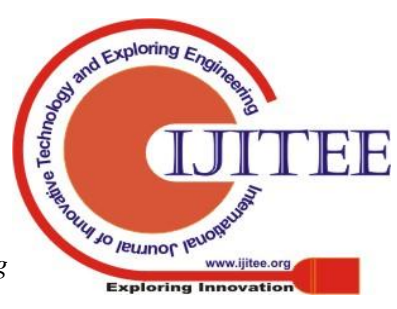


behavior can result in some damage. Damage that occurred in the form of fractures/fragments of coral reefs in snorkeling sites and there are many hard corals that died due to trampling or fins flapping.

This is in accordance with the study of Frederick et al (2005) that contact fin is the behavior most often done by tourists and has the potential to damage corals in addition to stirring sediment behavior. The results of measurements of the extent of coral cover at Station III are shown in tables 5 and 6.

TABLE 5. THE RESUlTS OF THE MEASUREMENT OF CORAL COVER STATION III DEPTH OF 2 METERS

\begin{tabular}{|c|c|}
\hline \multicolumn{2}{|c|}{ Station III Depth 2 Meters } \\
\hline Kategory & $\%$ Cover \\
\hline ACT & $23.9 \%$ \\
CB & $7.4 \%$ \\
ACB & $6.3 \%$ \\
CS & $1.7 \%$ \\
CMR & $3.3 \%$ \\
CF & $2 \%$ \\
ACD & $33.5 \%$ \\
CTU & $1.7 \%$ \\
CME & $2.4 \%$ \\
CM & $1.8 \%$ \\
CE & $2.5 \%$ \\
\hline Total & $86.5 \%$ \\
\hline
\end{tabular}

Ket : ACT (Acropora tabulate), CB (Coral branching), ACB (Acropora branching), CS (Coral ubmassive), CMR (Coral mushroom), CF (Coral foliose), ACD (Acropora digitate) CTU (Coral tubupora), CME (Coral milepora), CM (Coral massive) dan CE (Coral encrusting).

TAble 6. Measurement Results of Coral Cover STATION III DEPTH OF 4 METERS

\begin{tabular}{|c|c|}
\hline \multicolumn{2}{|c|}{ Station III Depth 4 Meters } \\
\hline Kategory & \% Cover \\
\hline ACT & $27.1 \%$ \\
CB & $11.5 \%$ \\
ACD & $35.5 \%$ \\
ACB & $3.9 \%$ \\
CS & $2.5 \%$ \\
CTU & $5.2 \%$ \\
CMR & $4.2 \%$ \\
CM & $5.5 \%$ \\
\hline Total & $95.4 \%$ \\
\hline
\end{tabular}

Ket : ACT (Acropora tabulate), CB (Coral branching), ACB (Acropora branching), CS (Coral submassive), CMR (Coral mushroom), ACD (Acropora digitate) CTU (Coral tubupora), CM (Coral massive).

In tables 5 and 6. The ACD (Acropora digitate) coral species is the type that has the highest percentage of coral lifeform at station III. Acropora corals are hard coral fast-growth species (species with high growth speed) whose growth reaches $15 \mathrm{~cm} /$ year, but these corals are also easily damaged due to their fragile structure and are not resistant to environmental stresses such as currents, waves, and high sedimentation. (Suharsono, 1984). This is in accordance with the location of Station III where the substrate is hard and permanent, has a relatively low current speed. Monk et al (2000) that the substrate is very important as a place to attach the larvae. Coral larvae need a hard substrate as a place to stick. Inappropriate substrate will reduce the rate of coral growth.

\subsection{Diversity of Coral Reefs in the Olele Regional Marine Protected Area}

Diversity of lifeform types of coral reefs in the Olele marine park conservation area can be seen in table 7. Based on the calculation of diversity index, it can be seen the highest coral reef diversity index value in the KKLD Olele found at station III (N 00o24'52.5 "E 123o08'52.3") of (2.30) compared to the diversity index value in station II $(\mathrm{N}$ 00o24'32.6 "E 123o09'07.0") (1.96) and Station I (N 00o24'40.4 "E 123o09'08.8"). (1.62). In general, the index of coral reef diversity in the KKLD Olele is in the moderate category. Rachmaway (2011) states that the diversity of an area is also influenced by environmental factors such as nutrient sources, inter and intra-species competition, disturbance, and conditions of the surrounding environment so that species that have a high tolerance will increase while those who have low tolerance will decrease.

\section{TABLE 7. INDEX OF DIVERSITY OF CORAL REEFS IN THE} Olele Marine Park-Conservation Area

\begin{tabular}{|c|c|c|c|c|}
\hline No & Station & Diversity Index (H') & Benchmark & Information \\
\hline 1. & I & 1.62 & $1,0>\mathrm{H}^{\prime}<3,322$ & Sedang \\
\hline 2. & II & 1,96 & $1,0>\mathrm{H}^{\prime}<3,322$ & Sedang \\
\hline 3. & III & 2,30 & $1,0>\mathrm{H}^{\prime}<3,322$ & Sedang \\
\hline
\end{tabular}

\section{CONCLUSION}

The condition of coral cover in the marine conservation area of the Olele area and the index of diversity of coral reef species in moderate condition. Decreasing the condition of coral cover at each station is influenced by several factors such as environmental factors one of which is marine tourism activities.

\section{ACKNOWLEDGEMENT}

Gratitude to University Gorontalo and KEMENRISTEK DIKTI writer thank you for the opportunity that had given them so that research PKPT can be done well.

\section{REFERENCES}

1. Dahuri, R. 2003. Keanekaragaman Hayati Laut: Aset Pembangunan Berkelanjutan Indonesia. PT Gramedia Pustaka Utama, Jakarta. 412 hal.

2. English, S., C. Wilkinson, and V. Baker. 1997. Survey Manual For Tropical Marine Hal. 48.

3. Frederick, A., V.E.C. Caidenc, J.L.D. Perez, and T. Danilo. 2005. Impact of Recreational Scuba Diving on a Marine Protected Area in Central Philippines: A Case of Gilutongan Marine San-cuary. Phillip Science, 42: 144-158.

4. Gomez, E. D. and Yap, H. T. 1988.Monitoring Reef Condition in: Kenchington, R. A.and B. E. T. Hudson (ed.): Coral Reef Management Hand Book.

5. Rachmawaty, (2011). Macrozoobenthos Diversity Index as Bioindicator of Pollution Level in the Jeneberang River Estuary. Journal of Bionature, Department of Biology, Faculty of Mipa, Makassar State University Vol. XII No. 2 (In Indonesia)

6. Suharsono, 1998. Distribution, Methodology and Status of Coral Reefs in Indonesia. Indonesian National Conference on Coastal and Ocean Resource Management. PKSPL. IPB. (In Indonesia) 


\section{AUTHORS PROFILE}

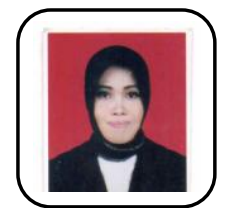

Asniati Ningsi, Lecturer at Gorontalo University, Fisheries and Maritime Department, Faculty of Agriculture. Title of Publication : The Extract Welch Starfruit Leaves of Water Levels, Proteins and Fats Skipjack (Katsuwanus pelamis), Publication at International Journal of Advance Science Education and Relegion, STAI Al-Furqan Makassar. Indonesia and Long Relationship ad Weight Total Shellfish (Polymesoda erosa) In The Mangrove Ecosystem In Sinjai District Publication In STITEK Balik Diwa Makassar. As a member of the Indonesian Associations of Oceanologist.

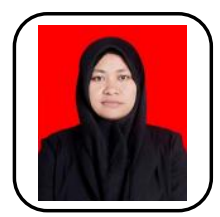

Ida Astuti, Lecturer at Gorontalo University, Fisheries and Maritime Department, Faculty of Agriculture. Title of Publication : The Effect of Wuluh Starfruit Leaf Extract Against Hstamin in Smoke Cakalang (Katsuwanus pelamis), Publication at Gorontalo Fisheries Journal, Kadar Abu, BETN, and Fiber Cakalang Asap With Soiling Extract of Wuluh Belimbing Leaf Publication at Galung Tropika Journal, Formaldehyde Test and $\mathrm{pH}$ of Julung Julung Fish (Hemiramphus brasilirnsis) Smoke in Traditional Markets Gorontalo City Publication at International Journal of Advance Science Education and Relegion, STAI Al-Furqan Makassar

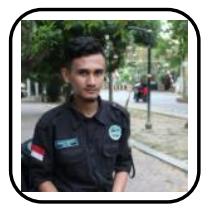

Ramdan Monoarfa, Student of the Faculty of Agriculture, Fisheries and Maritime Deapartment, Gorontalo University 